\title{
Assessment of Noni (Morinda citrifolia L.) Product Authenticity by Solid State Voltammetry
}

\author{
Douglas Vieira Thomaz ${ }^{1}$, Renê Oliveira Couto ${ }^{2}$, Aline de Oliveira Roberth ${ }^{1}$, Leandra Almeida Ribeiro \\ Oliveiral $^{1}$, Karla Carneiro de Siqueira Leitel, Maria Teresa de Freitas Bara ${ }^{1}$, Paulo César Ghedini ${ }^{3}$, \\ Marize Campos Valadares Bozinis ${ }^{1}$, German Sans Lobón ${ }^{1}$, Eric de Souza Gil ${ }^{1}$, \\ Fabio Bahls Machado, ${ }^{1,}$ \\ ${ }^{1}$ Faculdade de Farmácia, Universidade Federal de Goiás, Goiânia - GO, 74605-170, Brazil. \\ ${ }^{2}$ Universidade Federal de São João del-Rei, Curso de Farmácia, Campus Centro-Oeste / Dona Lindu \\ (CCO), 35501-296, Divinópolis - MG, Brazil. \\ ${ }^{3}$ Instituto de Ciências Biológicas, Universidade Federal de Goiás, 74001-970 Goiânia - GO, Brazil. \\ *E-mail: famafarm@yahoo.com.br
}

doi: $10.20964 / 2018.09 .390$

Received: 5 April 2018 / Accepted: 15 May 2018 / Published: 5 August 2018

\begin{abstract}
Noni (Morinda citrifolia L.) is a native fruit from Southeast Asia and Australia, widespread in tropical countries. Diverse pharmacological activities have been attributed to its raw material and products, which contain appreciable phenolic content. This paper reports the use of electrochemical methods to evaluate Noni products authenticity. Therefore, standard pharmacognostic and chromatographic techniques (TLC-UV and HPLC-PDA) were employed in order to compare the results of electroanalytical assays. An authenticity pattern for the studied samples was achieved. We also have demonstrated that the specificity and selectivity of a novel solid state differential pulse voltammetry method was comparable to both TLC-UV and HPLC-PDA results for main chemical markers detection i.e., scopoletin and rutin. Henceforth, our electroanalytical method can be a useful strategy for a quick and cheap authenticity assessment of Noni foodstuff.
\end{abstract}

Keywords: chromatography, electrochemistry, electrodes, herbal medicine, Morinda citrifolia.

\section{$\underline{\text { FULL TEXT }}$}

(C) 2018 The Authors. Published by ESG (www.electrochemsci.org). This article is an open access article distributed under the terms and conditions of the Creative Commons Attribution license (http://creativecommons.org/licenses/by/4.0/). 